\title{
Gomaya churneeyam of Bhela Indriya Sthana - An explorative study
}

\begin{abstract}
'Maharshi Bhela' is one among the six disciples of 'Acharya Punarvasu Atreya' and he has composed a treatise known as 'Bhela samhita'. Bhela samhita is having 8 sections and 120 chapters. Indriya sthana is one among the 8 sections of 'Bhela samhita' deals with prognostic aspects. Among 12 chapters of 'Bhela indriya sthana', 'Gomaya churneeyam' is the 9 th chapter which comprises of 21 verses dealing with various emergency conditions having poor prognosis. The contents of 'gomaya churneeyam' are unique and further in-depth exploration is required. Previous works conducted on 'Charaka indriya sthana' and 'Bhela indriya sthana' have explored various hidden concepts having both clinical and prognostic significance. Studies on 'gomaya churneeyam' of 'Bhela indriya sthana' have been lacking and the present study is aimed to explore the contents of this chapter in terms of its prognostic significance. Various conditions like seborrheic dermatitis in an immunocompromised patients, extra pulmonary tuberculosis, nasopalatine duct cyst, age related macular degeneration, oral malignant melanoma, trigeminal autonomic cephalgia, lateral medullary syndrome, periodontitis, autonomic dysreflexia, systemic lupus erythematosus, limbic encephalitis, temporal lobe epilepsy, congenital erythropoeitic porphyria, white spot lesions, sub conjunctival haemorrhage, chronic kidney disease, endof-life dreams and visions, fever of unknown origin and chronic widespread pain associated with mortality have been documented in 'Gomaya churneeyam' of 'Bhela indriya sthana'. Further works are required to establish the facts documented in this chapter.
\end{abstract}

Keywords: bhela indriya sthana, bhela samhita, charaka indriya sthana, end of life stages, indriya sthana, prognosis
Volume I4 Issue I - 202 I

\section{Prasad Mamidi, Kshama Gupta}

Department of Kayachikitsa, SKS Ayurvedic Medical College \& Hospital, India

Correspondence: Prasad Mamidi, Dept of Kayachikitsa, SKS Ayurvedic Medical College \& Hospital, Mathura, Uttar Pradesh, India,Tel +9l 7567222856, Email drprasadmamidi@gmail.com

Received: November 30, 2020 | Published: January 2I, 2021

\begin{abstract}
Abbreviations: SD, seborrheic dermatitis; AIDS, acquired immunodeficiency syndrome; HIV, human immunodeficiency virus; $\mathrm{PD}$, parkinson's disease; $\mathrm{AD}$, alzheimer's disease; $\mathrm{TB}$, tuberculosis; EPTB, extra pulmonary tuberculosis; DIC, disseminated intravascular coagulopathy; NPDC, nasopalatine duct cyst; ABC, aneurysmal bone cyst; AMD, age related macular degeneration; LHS, laugier-Hunziker syndrome; PJS, Peutz-Jeghers syndrome; $\mathrm{OMM}$, oral malignant melanoma; $\mathrm{ACTH}$, adrenocorticotropic hormone; SUNCT, short-lasting unilateral neuralgiform headache attacks with conjunctival injection and tearing; TAC, trigeminal autonomic cephalgia; MS, multiple sclerosis; SPG, sphenopalatine ganglion; NMOSD, neuromyelitis optica spectrum disorder; SUNA, short-lasting unilateral neuralgiform headache attacks with cranial autonomic symptoms; LMI, lateral medullary infarction; PICA, posterior inferior cerebellar artery; LMS, lateral medullary syndrome; ICA, Internal carotid artery; LE, lupus erythematosus; SLE, systemic lupus erythematosus; DLE, Discoid lupus erythematosus; AD, autonomic dysreflexia; SCI, spinal cord injury; ANS, autonomic nervous system; IP, Ictal piloerection; TLE, temporal lobe epilepsy; LE, limbic encephalitis; CEP, congenital erythropoeitic porphyria; WSL, white spot lesions; $\mathrm{SCH}$, sub conjunctival haemorrhage; CCFs, carotid cavernous fistulas; GFR, glomerular filtration rate; CKD, chronic kidney disease; EPO, erythropoietin; Hb, haemoglobin; CNS, central nervous system; PRES, posterior reversible encephalopathy syndrome; NMS, neuroleptic malignant syndrome; GCS, glasgow coma scale; ICU, intensive care unit; ELDV, EOL dreams and visions; EBV, epstein-barr virus; CMV, cytomegalovirus; FUO, fever of unknown origin; OM, otitis media; TAO, thromboangiitis obliterans; PAD, peripheral artery disease; NBT, non-beneficial treatments; EOL, End-of-life stages;
\end{abstract}

\section{Introduction}

Maharshi Bhela and his five colleagues Maharshi Agnivesha, Jatukarna, Parashara, Harita and Ksharapani were the disciples of 'Acharya Punarvasu Atreya'. 'Maharshi Bhela' has composed an Ayurvedic treatise known as 'Bhela samhita' (1000 - 2000 BC) and it was quoted by a number of authors and commentators. Planning and arrangement of the contents in the 'Bhela samhita' is similar to that of 'Charaka samhita'. Bhela samhita has a number of unique ideas which were hidden and unexplored till date. ${ }^{1}$ Bhela samhita consists of 120 chapters and 8 sections similar to that of 'Charaka samhita'. 'Indriya sthana' is one among the eight sections of 'Bhela samhita' and it is comprised of 12 chapters. 'Indriya sthana' deals with various 'Arishta lakshanas' (fatal signs and symptoms) which denotes poor prognosis and an imminent death. ${ }^{2}$

'Gomaya churneeyam' is the 9th chapter of 'Bhela indriya sthana' which consists of 21 verses. This chapter deals with some arishta lakshanas which denotes an imminent death. ${ }^{3,4}$ Previous works conducted on 'Charaka indriya sthana' ${ }^{5-18}$ and 'Bhela indriya sthana' ${ }^{19}$ have established their clinical and prognostic significance. The contents of 'gomaya churneeyam' are unique and needs further in-depth exploration. The present is aimed to evaluate the contents of 'gomaya churneeyam adhyaya' in scientific terms. Studies on 'gomaya churneeyam adhyaya' of 'Bhela indriya sthana' have been lacking and the present study is planned to explore the contents of this chapter in terms of its prognostic significance.

\section{Review methodology}

A literature search has been undertaken. Both 'Google' and 'Google scholar' databases have been used for search. Full text 
articles with open access and abstracts published in 'English' were only considered. Articles published until November 2020, were only considered irrespective of their publication year or date of appearance. Ayurvedic literature (books and articles) published on 'Indriya sthana', 'Charaka indriya sthana', 'Bhela indriya sthana', and 'Arishta lakshanas' was considered. Articles related to emergency medicine and having prognostic importance have been searched from electronic databases by using relevant key words. No filters were applied during search. Authentic textbooks and pertinent websites were also referred.

\section{Exploration of the contents of gomaya churneeyam}

'Purnam shirasi yasyaiva -- maasaaddeham jahaati sa' (Verse 1) ${ }^{3,4}$

Scalp appears as covered with a dried powder of cow dung (gomaya churnam) which is unctuous (snehino) indicates an imminent death within a month (maasaaddeham jahati sa). The word 'gomaya churnam' denotes cow dung like powder (dandruff) and 'snehino' denotes unctuousness or excessive sebum. Similar verse is documented in 'Charaka indriya sthana', 12th chapter (gomaya chureeyam indriyam adhyaya) and it was correlated as 'SD in an immunocompromised patient'. ${ }^{16} \mathrm{SD}$ is a chronic inflammatory skin disorder commonly seen in immunocompromised patients characterized by periods of remissions and exacerbations. The incidence of SD markedly increases in patients with AIDS. Dandruff (pityriasis sicca) is a fine scalp scaling considered as part of the adult SD spectrum. The scalp scaling associated with SD and dandruff is troublesome due to continuous shedding of these flakes (gomaya churnam) from the scalp. SD is associated with increased sebum secretion (senhino). Malassezia species have been found in immunocompromised patients. $\mathrm{SD}$ is seen in persons with an increased sebaceous gland activity (snehino), patients suffering with immunodeficiency (lymphoma \& HIV-AIDS), neurological conditions (PD, AD, stroke and autonomic dysfunction), psychiatric conditions (major depression) and low ambient temperatures. ${ }^{16}$ The present verse denotes a condition of SD or Malassezia infection in an immunocompromised patient which may indicates death within a month.

'Krushasya kapha rogena -- dvau maasau naativartate' (Verse $2)^{3,4}$

The emaciated person (krushasya) having a kapha disease (respiratory diseases with cough and sputum production), cachexia (parikshaya) and aural bleeding (karnau raktam) with hemoptysis (raktau mukham) will die within two months (dvau maasau naativartate). The present verse denotes conditions like TB or ЕРТВ or lung carcinoma with metastasis to middle ear and temporal bone. Respiratory tract bleeding (epistaxis and hemoptysis) (raktau mukham) may be a marker of cancer (dvau maasau naativartate?) at several sites. Cancer-associated bleeding (karnau raktam \& raktau mukham) may be caused by tumour compression or invasion of blood vessels, or by DIC, thrombocytopenia, or platelet abnormalities. Haemoptysis (raktau mukham) is also frequently seen in cancers and it varies from blood-streaked sputum to coughing up large amounts of pure blood (raktau mukham). Causes of hemoptysis include malignancy, pulmonary embolism and other vascular causes, infection, trauma, inflammation, and bronchiectasis. ${ }^{20}$ Coughing up bright red blood or blood clots (raktau mukham) can be seen in carcinoma of the lung, tuberculosis (sleshma parikshaya?) and pulmonary embolism. Bloodstreaked, purulent sputum (raktau mukham) can be seen in bronchitis, bronchiectasis, or pneumonia and blood-tinged, white, frothy sputum is seen in congestive heart failure. Foul-smelling and bloody sputum (raktau mukham) in found in an anaerobic lung abscess. Hemoptysis in lung cancer (dvau maasau naativartate?) or tuberculosis (sleshma parikshaya?) usually is a late symptom preceded by weight loss (krushasya), change in cough (kapha rogena), fatigue, and other chronic symptoms. ${ }^{21}$ Bleeding from the ear (karnau raktam) is presumably the most significant symptom and it may occur early in cancer (middle ear and mastoid) (dvau maasau naativartate?). ${ }^{22}$ The clinical picture demonstrated in the present verse denotes TB or EPTB or lung carcinoma metastasis to middle ear or temporal bone associated with cachexia.

\section{'Yasya lohitakaabhaasa -- sa maasam naativartate' (Verse 3) $)^{3,4}$}

The emaciated or cachexic person having a reddish cyst like swelling at palate will die within a month. The word 'lohitakaabhaasa' denotes reddish lesion and 'ambu' denotes cystic swelling. The present verse denotes various conditions such as NPDC, ABC, radicular cysts, hemangiomas, mucoepidermoid carcinoma, pleomorphic adenoma, squamous cell carcinoma, non-Hodgkin's lymphoma, and metastasis in the oral cavity and maxillofacial region. ${ }^{23}$ NPDC is located on the palatal aspect (taaluni drushyate) in midline of maxilla and it is the most common developmental, non-neoplastic, non-odontogenic cysts of the oral cavity. Odontogenic cysts (e.g., lateral radicular cyst, lateral periodontal cyst, odontogenic keratocyst), odontogenic tumors (e.g., ameloblastoma, odontogenic myxoma) and non-odontogenic tumors (e.g., central giant tumor, brown tumor of hyperparathyroidism, central hemangioma) etc conditions should be considered in the differential diagnosis of NPDC. NPDC may give rise to squamous cell carcinoma (sa maasam naativartate?) in the anterior zone of the upper maxilla. ${ }^{24} \mathrm{ABC}$ lesions are nonneoplastic, locally aggressive and have high recurrence rates. $\mathrm{ABC}$ is an expansive osteolytic lesion consisting of blood-filed spaces (lohitakaabhaasa) and channels divided by connective tissue septa that can contain osteoid tissue and osteoclast-like giant cells. Hemorrhage (lohitakaabhaasa) can occur, especially if the alveolar bone is involved. Aspiration of a dark red or brownish hemorrhagic fluid (lohitakaabhaasam ambu) is suggestive of $\mathrm{ABC} .^{25}$

Radicular cysts are inflammatory jaw cysts and they develop as a consequence of advanced carious lesions. Increased vascularity with numerous dilated endothelial lined blood capillaries and thickened vessels filled with RBCs are evident along with areas of haemorrhage (lohitakaabhaasam ambu). Radicular cysts may become large enough to extensively erode adjacent bony structures (sa maasam naativartate?). ${ }^{26}$ Hemangiomas are blood vessel tumours occasionally seen on the palatal mucosa (taaluni drushyate), can occur as a capillary or cavernous type. The lesions may be bright-red, erythematous (lohitakaabhaasam ambu), and bilobulated with well-defined margins. Capillary hemangioma is associated with gingival vascular features and complications (sa maasam naativartate?) in the form of impaired nutrition and oral hygiene, increased accumulation of plaque and microorganisms, and increased susceptibility to oral infections, which can impair the systemic health of the affected individual. Chances of profuse bleeding (sa maasam naativartate?) are always a threat while dealing with hemangiomas. ${ }^{27}$

\section{'Arundhati na pashyet -- kshipram praan aur vimuchyate' (Verse} $4)^{3,4}$

The person unable to see (na pashyet) a star called 'Arundhati' in the sky (constellation of saptarshi) will die (praan aur vimuchyate) within 8 months (maasaadashtamaan). Various ocular disorders (e.g., visual impairment and cataract and in persons with diabetes mellitus, severe retinopathy and visual impairment) have been reported to be significant predictors of a decreased life span (praan aur vimuchyate). Ocular disorders, in particular cataract, may be markers of systemic 
processes that are associated with accelerated physiologic aging and earlier death (maasaadashtamaan). It has been established that nuclear cataract and AMD might each be associated with a major cause of death (praan aur vimuchyate), that is, cancer and diseases of the circulatory system, respectively. ${ }^{28}$ Even mild visual impairment (na pashyet) increases the risk of death (praan aur vimuchyate) more than twofold. An association between age related eye conditions and increased mortality (praan aur vimuchyate) has been established. It is plausible that people with vision impairment (na pashyet) have increased mortality for a number of reasons such as increased falls, risk of accidents, nuclear opacities (especially in diabetic patients), glaucoma, and AMD. It has been established that that decreased visual acuity is associated with increased mortality (praan aur vimuchyate). ${ }^{29}$ Visual impairment (na pashyet) is associated with psychosocial conditions including social isolation, cognitive impairment, increased dependency on others, poor self-rated health, and depression. Poor vision (na pashyet) in older adults has a greater impact on overall mental health than stroke and heart attack (praan aur vimuchyate?) Persons with visual impairment (na pashyet) have reduced mental well-being and that mental well-being is a strong predictor of mortality (praan aur vimuchyate) has been established. ${ }^{30}$ The present verse denotes a condition of visual impairment (due to various ocular and systemic disorders or diseases) associated with mortality.

\section{'Anukaabhishcha -- na sa jeevati taadrusha' (Verse 5) ${ }^{3,4}$}

The person who is having small or minute (anukaabhi), black or brownish-black or bluish-black or gray coloured (krishnaabhi), confluent (anucchhinnam), hyperpigmented or melanotic lesions in the oral mucosa (aasya), tongue (jihwa) and palate (taalu) will die soon (na sa jeevati). The present verse denotes various life threatening conditions associated with oral melanotic macules. Increase in melanin content (krishnaabhi) of the oral epithelium (aasya) occurs in several conditions. The oral melanotic macule is a small (anukaabhi), discrete, brownish-black (krishnaabhi), flat lesion of the oral mucosa (aasya). Multiple, small (anukaabhi), melanotic macules in oral mucosa (aasya) can be seen in PJS. The oral mucosal pigmentary changes may occasionally be the earliest sign of Addison's disease (increased ACTH). ${ }^{31}$ Labial and oral melanotic macules (krishnaabhi aasya) are commonly encountered in a broad range of conditions ranging from physiological pigmentation to a sign of an underlying life-threatening disease (na sa jeevati). The most common lesion sites in LHS are the lips, the oral cavity (aasya), the tongue (jihwa), gingiva, and palatal mucosa (taalu). Typically, the cutaneous or mucosal lesions manifest as gray, brown, blue-black, or black macules (krishnaabhi) with a flat, smooth surface and relatively well-defined or indistinct margin (anucchhinnam) having the size of 2 to $5 \mathrm{~mm}$ in diameter (anukaabhi) and lenticular, oval, or irregular in shape. Hyper pigmented macules (krishnaabhi) are distributed in variable numbers. Single or multiple lesions are observed, and occasionally, the lesions are confluent (anucchhinnam). Labial and OMM can be seen in various other conditions such as melanotic macule, mleanocytic nevus, melanocanthoma, oral melanoma, PJS, McCune-Albright syndrome, Neurofibromatosis type 1, Carney complex, LEOPARD syndrome and Cronkhite-Canada syndrome. ${ }^{32}$ The lesions in oral melanotic macule may be elevated and a well-defined blackishbrown colour (krishnaabhi) discolouration present on right buccal (aasya) and lingual mucosa (jihwa). Various conditions such as oral melanotic macule, melanoplakia, pituitary-based Cushings syndrome, post-inflammatory pigmentation, melanoacanthoma, amalgam tattoo, Addisons disease, PJS and melanocytic nevi should be considered in the differential diagnosis of OMM. Poor prognosis of melanoma (na sa jeevati) may be due to early invasion of deeper structures due to proximity of bone and muscles increasing likelihood of metastasis. ${ }^{33}$

\section{'Sheershaabhitaapino -- naayamasteeti nirdishet' (Verse 6)}

The person who has been suffering with headache (sheershaabhitaapino), respiratory symptoms (sleshma rogavata), hiccups (hikka) and rhinorrhea (vinishyandate) will die soon (naayamasteeti nirdishet). The present verse denote various conditions such as LMI, LMS, NMOSD, SUNA, SUNCT, SPG, TAC with or without MS, pituitary apolplexy, pulmonary embolism, lower lobe pneumonia, acute or chronic upper or lower respiratory tract infections and their complications. LMS or Wallenberg syndrome is known to be associated with multitudes of peculiar symptoms such as hiccups (hikka), rhinorrhea (vinishyandate) and headache (sheershaabhitaapino) in patients. Patients of LMS in the distribution of the PICA have shown intermittent rhinorrhea (vinishyandate). Rhinorrhea (vinishyandate) can be a part of the autonomic symptom of cluster headache (sheershaabhitaapino) and SUNCT. ICA dissection can be associated with a clinical picture consistent with cluster headaches (sheershaabhitaapino). The lateralized rhinorrhea (vinishyandate) suggests that the underlying cause is stroke and previous studies have reported the occurrence of contra-lateral rhinorrhea (vinishyandate) after a right caudate infarct. ${ }^{34}$ Middle level and dorsolateral lesion locations in LMI can induce hiccups (hikka) frequently. Hiccups (hikka) are an infrequent result of LMI. Patients with LMI presenting with hiccups have also shown vertigo, dizziness, nausea (sleshma rogavata?), vomiting (sleshma rogavata?), and dysphagia. ${ }^{35}$

TAC is a primary headache syndrome (sheershaabhitaapino) characterized by severe short-lasting unilateral headaches with ipsilateral cranial autonomic symptoms. Previous studies have described the association of TAC-like headache with intracranial lesions (e.g., pituitary adenomas, arteriovenous malformation of frontal and temporal lobes, brain tumour in posterior fossa, vertebral artery aneurysm, and orbitosphenoidal aspergillosis). Ipsilateral tearing, rhinorrhea (vinishyandate), eye reddening and hiccups (hikka) were found in patients of MS presenting with TAC. ${ }^{36}$ SPG is the largest collection of neurons in the calvarium outside of the brain and it is also known as pterygopalatine ganglion, nasal ganglion or Meckel's ganglion. SPG has been postulated to be involved in facial pain and headaches (sheershaabhitaapino) for over a century. TAC is characterized by parasympathetic (lacrimation, rhinorrhea, nasal congestion and edema) (sleshma rogavata?) activation and sympathetic dysfunction. Persistent hiccups (hikka) can also be seen in patients of SPG. ${ }^{37}$ Intractable hiccups (hikka), vomiting, lacrimation, and ispilateral rhinorrhoea (vinishyandate) can be seen in NMOSD patients. SUNA / SUNCT are rare forms of TAC and can be found in patients of NMOSD. ${ }^{38}$

\section{'Yasya lomaani keshaashcha -- na sa jeevati taadrusha' (Verse 7)}

A person whose hairs on the body (lomaani) and the head (keshaani) appear as if being scorched or singed (plushyanteeva) or hairs standing up (horripilation or goose bumps or piloerection) (samhrushtaaneeva), that person will not survive (na sa jeevati). The word 'pulshyanteeva lomaani or keshaani' denotes a pathological condition called 'lupus hair' and 'samhrushtaaneeva lomaani' denotes piloerection (due to various underlying fatal systemic diseases). Dry and fragile (plushyanteeva) short hairs on the frontal hairline of patients with lupus are termed as 'lupus hair' (plushyanteeva keshaani) because this sign is so striking that it can suggest the diagnosis of SLE. LE is a chronic multi-organ autoimmune disease (na sa jeevati?) with a spectrum of clinical and serological presentations. The major target organs are the joints, skin, kidneys, lungs, and the nervous and serous systems (na sa jeevati?). In DLE patients, hair on the affected sites is usually brittle (plushyanteeva) and easily detachable. ${ }^{39}$ Piloerection 
(samhrushtaaneeva) can be seen in AD due to SCI (especially injury which has occurred above T6 level). Dysregulation of the ANS leads to an uncoordinated autonomic response that may result in a potentially life-threatening hypertensive episode (na sa jeevati?) when there is a noxious stimulus below the level of the SCI. ${ }^{40}$ Pale, cold skin and piloerection (samhrushtaaneeva) are seen below the level of the lesion (in $\mathrm{AD}$ due to SCI). ${ }^{41}$ Altered autonomic function including piloerection (samhrushtaaneeva) can be seen in "Autonomic seizures'. ${ }^{42}$ IP (samhrushtaaneeva) is a rare ictal manifestation that occurs predominantly in patients with TLE. Unilateral piloerection (samhrushtaaneeva) is generally associated with ipsilateral focal epilepsy. ${ }^{43}$ IP is considered to be autonomic epilepsy, and has been reported in many neurological diseases, especially in LE (na sa jeevati?). It has been established that pilomotor seizures (samhrushtaaneeva) as a specific section of multiple seizures are frequently associated with LE. ${ }^{44}$ Piloerection (samhrushtaaneeva) is one among the various clinical signs of heart failure (na sa jeevati?). ${ }^{45}$

\section{'Yasya kaalaantare dantaa -- na sa jeevati taadrusha' (Verse 8) ${ }^{3,4}$}

Reddish discoloration (rakta sannibha), lack of lustre (nishprabha) and plaque formation (anulipta) of teeth (danta) denotes an impending death. 'Rakta sannibha dantaa' denotes erythrodontia, 'nishprabha' denotes lack of dental lustre due to demineralization or hypominerilazation or dental erosion and the word 'anulipta' denotes dental plaque formation. Dental pathological conditions like 'asthi shweta' (WSL) and 'panka samvrita' (dental plaque formation) are considered as arishta lakshanas according to 'Avaakshriaseeyam' chapter of "Charaka indriya sthana" ${ }^{2}$ Reddish discoloration (rakta sannibha) of teeth (danta) has been found in CEP. CEP is an autosomal recessive metabolic disease, with mutation in the gene that codifies uroporphyrinogen-III synthtetase, leading to porphyrin accumulation in skin, bone, urine and dentine. A red-purple or redbrown discoloration (erythrodontia) (rakta sannibha) in the primary and permanent teeth can be seen in CEP patients. Reddening (rakta sannibha) of the upper central incisors (danta) can be seen in patients with lepromatous leprosy. ${ }^{46}$

Teeth with loss of lustre (nishprabha), surface roughness and visible cavitation recognized as carious. ${ }^{47}$ The destruction of tooth structure through caries and erosive processes is due to acidic challenges. Acidic attack by cariogenic bacteria initially produces subsurface lesions that weaken the enamel and can progress through the enamel, dentin and up to the pulpal cavity. Erosive attack by acidic foods and beverages removes mineral from the surface of enamel and causes dulling \& loss of tooth luster (nishprabha) and it can progress to a more severe loss of enamel thickness and contour. ${ }^{48}$ Visual clues like decreased surface lustre on enamel (dantaa nishprabha) and dentine may be an indicator of acid dissolution of the tooth surface. Lack of reflectivity of the tooth surface (nishprabha) and possibly indicate a reduction in surface mineralization. ${ }^{49}$ WSLs are subsurface enamel porosity from carious demineralization that presents as a milky white opacity (dantaa nishprabha). WSLs are clinical manifestations of early enamel caries characterized by their opacity (dantaa nishprabha), mineral loss, and decrease of fluorescence radiance (dantaa nishprabha). Incipient dental carious lesions are associated with plaque accumulation (anulipta) and manifest as chalky white areas of discoloration secondary to demineralization. Periodontal disease encompasses periodontitis and gingivitis. Periodontitis develops over time with accumulation of dental plaque (anulipta), bacterial dysbiosis, formation of periodontal pockets (anulipta), gum recession, tissue destruction, and alveolar bone loss, halitosis and tooth loss. There is a positive association between periodontal disease and risk of lung, oral, and pancreatic cancers (na sa jeevati?). ${ }^{12}$

\section{'Kshaarena vidhrutam gaatram -- na cha sa jeevati taadrusha' (Verse 9) $)^{3,4}$}

Body (gaatram) appears (drushyate) as washed with caustics (kshaarena vidhrutam) in both hot and cold seasons (samamushne cha sheete cha) denote an impending death (na sa jeevati). The present verse denotes skin colour changes associated with or without edema (kshaarena vidhrutam gaatram) and temperature changes at the EOL stages (na sa jeevati). Change in skin colour (skin becomes deadly pale or earth like colour, skin colour drains or turns white, skin turns pale or other colour changes) (kshaarena vidhrutam gaatram?), edema (of whole body or extremities or instep or underside of foot) (kshaarena vidhrutam gaatram?), body temperature decline (samamushne cha sheete cha?), vital power decline, blood pressure decline, bedsore/ wound deterioration (kshaarena vidhrutam gaatram?), and cyanosis (kshaarena vidhrutam gaatram?) are some among the signs and symptoms shown by the senile dementia patients at the end stages of life (na sa jeevati).$^{50}$ The present verse explains the appearance of body or colour and temperature changes at the end stages of life.

\section{'Gaatreshu swara varneshu -- na cha sa jeevati taadrusha' (Verse $10)^{3,4}$}

The word 'vaarilava plava' (which floats on the water) denotes lightness or feebleness or decline. The person who shows body weight reduction or weight loss (gaatreshu vaarilava plava?), feeble voice (swareshu vaarilava plava?), decline of skin colour/ complexion or skin turns pale or white (varneshu vaarilava plava?) and excessive unctuousness or oiliness or greasiness even without application of oil (anabhyakteshu gaatreshu vaarilava plava?) or hyperhidrosis (anabhyakteshu gaatreshu vaarilava plava?) will leave or die soon (na cha sa jeevati) as per the present verse. Body weight reduction (gaatreshu vaarilava plava?) is commonly seen among the elderly with EOL dementia (na cha sa jeevati). Positive association between body weight reduction (gaatreshu vaarilava plava?) and the prognosis of elderly patients (na cha sa jeevati) has been established. Body weight reduction (gaatreshu vaarilava plava?) still occurs at the dementia EOL stage (na cha sa jeevati), even if the appropriate amounts of nutrition are given. Skin becomes deadly pale or earth like colour, draining of skin colour or colour turns white, skin turns pale or other colour changes of skin (varneshu vaarilava plava?) are some of the features among various signs and symptoms seen in EOL stages of senile dementia patients (na cha sa jeevati). ${ }^{50}$ Skin turns pale in colour and discoloration of skin can also be seen in advanced cases of cancer. ${ }^{5}$ Weakening or quietening of voice (swareshu vaarilava plava?) is one among many signs and symptoms to be anticipated in the last days of life (na cha sa jeevati).$^{51}$ Hyperhidrosis (excessive sweating) (vaarilava plava) can be seen in systemic disorders such as diabetes mellitus, hyperthyroidism, PD and other neurologic disordesr, and tumours such as pheochromocytoma and lymphoma (na cha sa jeevati) ${ }^{52}$ Seborrheic facies is a manifestation of PD and it presents as plaques with greasy scales (anabhyakteshu gaatreshu vaarilava plava?) in areas that have an increased density of sebaceous glands. Dyshidrosis, including hyperhidrosis (anabhyakteshu gaatreshu vaarilava plava?) and hypohidrosis, is a common feature of PD. SD in PD may be due to autonomic dysfunction. Dyshidrosis is considered as part of the spectrum of autonomic dysfunction in PD. Drenching sweats (vaarilava plava?) also have been described in PD patients. ${ }^{53}$ 


\section{'Shoolamange bhavet yasya -- paretam tasya jeevitam' (Verse 11) $)^{3,4}$}

Generalized body pains (shoolamange) (bursting or blowing nature) (sphutitam) associated with eye bleeding (inferior half of the eye balls) (raktamaasravet adho golakam) denotes an impending death (paretam tasya jeevitam). SCH is a painless acute appearance of a sharply circumscribed redness of bleeding (raktamaasravet) underneath the conjunctiva. It can vary from dot-blot haemorrhages to extensive areas of bleeding (raktamaasravet). SCH is most often seen in the inferior (adho golakam) and temporal areas of the conjunctiva. Local trauma, systemic hypertension, acute conjunctivitis, and diabetes mellitus are the main associated conditions of SCH. Among older patients $\mathrm{SCH}$ is mostly associated with systemic vascular disorders (systemic hypertension, diabetes, and arteriosclerosis) which cause the walls of the blood vessels to become fragile (raktamaasravet?). Systemic factors that may lead to $\mathrm{SCH}$ can be classified as systemic vascular diseases, sudden severe venous congestion, haematological dyscrasias, systemic trauma, acute febrile systemic diseases, and CCFs. Pathologies of the coagulation system (including the disorders associated with thrombocytopenia and platelet dysfunction) such as thrombocytopenic purpura, anaemia, leukaemia, splenic disorders, and uraemia may cause bleeding in conjunctival vessels (raktamaasravet)..$^{54}$ The eye is an important indicator of rheumatologic disease (shoolamange sphutitamiva). A wide variety of ophthalmic clinical manifestations exist including inflammation of the cornea, conjunctiva, lacrimal gland, episclera, sclera, uvea, and ophthalmic blood vessels (raktamaasravet?). Rheumatologic diseases (shoolamange sphutitamiva) and autoimmune disorders may manifest as a variety of ophthalmologic conditions with a wide range of signs and symptoms (raktamaasravet?). ${ }^{55}$ The present verse denotes an eye bleeding associated with a wide variety of systemic or rheumatological or autoimmune disorders.

'Aapaandu madhumehe tu -- panchatavam hi gacchati' (Verse 12) $)^{3,4}$

The person who has been suffering with severe anaemia (aapaandu), diabetes (madhumeha) and polyuria (mehati) will die (panchatvam gacchati) within five days (panchaahat). Anaemia (aapaandu) is one of the most common blood disorders seen in patients with diabetes (madhumeha) who also have renal insufficiency (mehati). Studies have also reported an incidence of anaemia (aapandu) in diabetics (madhumeha) prior to evidence of renal impairment (mehati?). Anaemia (aapaandu) occurs earlier and at a greater degree in patients presenting with diabetic nephropathy (mehati?). Anaemia (aapaandu) is also the commonest hematological manifestation in patients with malignant diseases (panchatvam gacchati). There is a significant association between a lower $\mathrm{Hb}$ concentration (aapaandu) and a decline in GFR (mehati?). Anaemia (aapaandu) has a negative impact on the survival of patients with diabetes (madhumeha) and is considered to be an important cardiovascular risk factor (panchatvam gacchati) associated with diabetes (madhumeha) and renal disease (mehati?). Anaemia (aapaandu) is a key indicator of CKD (mehati?) but occurs earlier in the course of diabetic kidney disease (madhumehe mehati) and may be more severe. In patients with diabetes (madhumeha), anaemia (aapaandu) may be the result of diminished EPO production by the failing kidney (mehati). Anaemia (aapaandu) is an early and common complication of (panchatvam gacchati) diabetes. ${ }^{56}$ The present verse denotes a condition of anaemia associated with diabetes and CKD or renal failure.

\section{'Aratishcha avipaakashcha -- na sa jeevati taadrusha'(Verse 13)}

The person who has been suffering with restlessness (arati), anorexia or loss of appetite or indigestion (avipaaka), weight loss or cachexia or sarcopenia (kaarshya) and weakness or vital power decline (daurbalya) will die soon (na sa jeevati). The present verse denotes a condition of anorexia-cachexia syndrome associated with delirium. Cachexia (kaarshya) is a complex metabolic process associated with underlying terminal illnesses (na sa jeevati) and it is characterized by anorexia (avipaaka) and loss of fat and muscle mass (daurbalya? kaarshya?). Loss of body weight (kaarhsya) and reduced energy levels (daurbalya) are also found in cachexia (kaarshya). Cachexia (kaarshya) is known to be associated with advanced dementia (na sa jeevati). Advanced stages of dementia are marked by substantial unintentional weight loss (kaarshya), malnutrition (avipaaka), sarcopenia (kaarshya? daurbalya?), anorexia (kaarshya), lethargy (daurbalya), altered immune function, and cachexia. The present verse denotes delirium due to an underlying terminal illness or delirium superimposed on advanced dementia patients with cachexia. Agitation (arati), restlessness (arati) and increased psychomotor activity (arati) are seen in delirium. During last days of life patients often experience progressive functional decline (daurbalya) and worsening symptom burden (na sa jeevati). Many symptoms such as anorexia-cachexia (avipaaka \& kaarshya), weight loss (kaarshya / daurbalya), decreased quality of life and delirium can be found in last days of life (na sa jeevati). ${ }^{18}$

\section{'Yastu deenam anaatho vaa -- yatha preta stathaiva sa' (Verse $14)^{3,4}$}

The person who has been suffering with depressed mood (deenam), loneliness or isolation or social withdrawal (anaatho), weakness or fatigue or lack of interest or anhedonia (balena pariheeyate) and hypochondriasis (bhidyam aarogam aapnoti) or feeling good while suffering with illness or disease (mithya arogyam aapnoti) should be considered as already dead (yatha preta stathaiva sa). The present verse denotes a wide variety of conditions like MDD, catatonia, negative symptoms of schizophrenia and mood disorders associated with poor prognosis. Depressed mood (deenam), anhedonia (loss of interest or pleasure in nearly all activities) (anaatho), significant weight loss (balena pariheeyate), psychomotor retardation (balena pariheeyate), fatigue or loss of energy (balena pariheeyate), feelings of worthlessness (anaatho) and interpersonal rejection sensitivity (anaatho) are the characteristic features of MDD. ${ }^{57}$ Catatonia of the retarded type is associated with signs reflecting a paucity of movement, including immobility, staring, mutism, rigidity, withdrawal (anaatho) and refusal to eat, along with more bizarre features such as posturing, negativism, grimacing, waxy flexibility, echolalia / echopraxia, verbigeration, stereotypy, and automatic obedience. Catatonia appears to be a risk factor for the development of neuroleptic malignant syndrome (which has a mortality rate of $10 \%$ ) (yatha preta stathaiva sa).$^{58}$ Negative symptoms are a core component of schizophrenia that account for a large part of the long-term disability and poor functional outcomes (yatha preta stathaiva sa) in patients with the disorder. The negative symptom domain consists of five key constructs: blunted affect (deenam), alogia (reduction in quantity of words spoken) (balena pariheeyate), avolition (reduced goal-directed activity due to decreased motivation) (balena pariheeyate), asociality (anaatho), and anhedonia (reduced experience of pleasure) ${ }^{59}$ Hypochondriasis is a unique disorder with the primary feature of persistent preoccupation (bhidyam aarogam aapnoti) with the possibility of having one or more 
serious physical disorders. Hypochondriasis is also noted to have an association with anxiety and depression (deenam). ${ }^{60}$

\section{'Anuvruttau yatha jantu -- yatha preta stathaiva sa' (Verse 15)}

The person who has been suffering with loss of consciousness (caused by pitta) (pittena parimurcchita) and making incomprehensible sounds or inappropriate words (sammudha vaakya) will die soon (yatha preta stathaiva sa). The present verse denotes a condition of coma caused by various underlying fatal conditions. Impaired consciousness (parimurcchati) can be considered in terms of reduced alertness or ability to be aroused, awareness or both, with coma defined as 'a completely unaware patient unresponsive to external stimuli (parimurcchati) with only eye opening to pain with no eye tracking or fixation, and limb withdrawal to a noxious stimulus at best'. The causative factors for non traumatic coma (parimurcchati) can be classified in to four main categories: neurological (ischemic stroke, intra-cerebral or subarachnoid haemorrhage, subdural hematoma, brain tumour, cerebral lymphoma, multiple brain metastases, CNS infections, cerebral abscess or oedema, hydrocephalus, axonic brain injury, PRES and trauma), metabolic (hypo / hyperglycaemia, hypo / hypernatraemia, hypercalcaemia, addisonian crisis, hypothyroidism, uraemia, hypercapnia and septic / hepatic encephalopathy), diffuse physiological brain dysfunctions (seizures, alcohol intoxication, opioid toxicity, poisoning, hypothermia, NMS and serotonin syndrome) and psychiatric or functional (psychiatric coma and malingering). Scores allotted for 'inappropriate words' and 'incomprehensible sounds' (sammudha vakya) in GCS are 3 and 2 respectively. Prognosis depends on a number of factors and the mortality rate varies from $25-87 \%$ in coma patients (yatha preta stathaiva sa). Non traumatic coma patients presenting with a stroke have the highest mortality (yatha preta stathaiva sa). Patients with a lower GCS at presentation 3 - 5 have a significantly higher mortality than those with a GCS of 7-10 (yatha preta stathaiva sa). ${ }^{61}$

'Yastvaasane atha shayane -- yashcha saashruni khaadati' (Verse 16) ${ }^{3,4}$

The person who has been suffering with restlessness or agitation (ratim na labhate) and not getting comfort in sitting (aasane) or lying (shayane) will die soon (sheeghram kurute kaalam). The present verse denotes the condition of terminal restlessness or terminal agitation seen in delirium. Delirium in the last few days of life (often referred to as terminal restlessness or terminal agitation) (sheeghram kurute kaalam) is often ongoing and irreversible. Hyperactive or agitated delirium is characterised by increased motor activity with agitation (ratim na labhate), hallucinations and inappropriate behaviour (ratim na labhate). Delirium is prevalent at the EOL (sheeghram kurute kaalam), particularly during the final 24-48hours. All patients at the EOL (sheeghram kurute kaalam) can be considered at high risk of delirium. ${ }^{6}$

\section{'Aaruhya vaanaram yastu -- swapne tu kushalaa naraa' (Verse} $17)^{3,4}$

The person who sees dreams (swapne) such as riding on a monkey (aaruhya vaanaram) and roaming without any purpose or objective (sankalpam naavabudhyate) should be considered as already dead (tamaahu paralokaaya). The present verse denotes ELDVs or delirium. Since ancient times, people have recorded dreams and visions (swapne) experienced by individuals (naraa) at the end of their lives (tamaahu paralokaaya). These experiences may involve visual, auditory and kinesthetic experiences (aaruhya vaanaram). ELDV experiences can occur months, weeks, days or hours before death (aaruhya vaanaram). ELDVs including a theme of going or preparing to go somewhere (aaruhya vaanaram) were common. ELDVs may be prognostically significant based on changes in dream content (aaruhya vaanaram) and increased frequency as death nears (tamaahu paralokaaya). The main quality of pre-death dreams (tamaahu paralokaaya) is a sense of personal meaningfulness. ${ }^{63}$ Discharged ICU patients often recall experience vivid dreams, hallucinations or delusions (aaruhya vaanaram). These dreams may be persecutory in nature and are sometimes very frightening also. It is possible that these memories stem from times when the patient was experiencing delirium, a common syndrome in the critically ill (tamaahu paralokaaya). A longer ICU stay was significantly associated with the experience of ICU dreaming (aaruhya vaanaram) ${ }^{64}$ In present verse, 'aaruhya vaanaram' and 'sankalpam naavabudhyate' (riding on a monkey and roaming on it without any objective or purpose) denotes agitation or restlessness or increased psychomotor activity etc. especially seen in delirium patients. The dream object or symbol mentioned in the present verse is 'monkey' (which is the displacement for patient), dream content (riding on a monkey without having any purpose) denotes underlying 'agitation' or 'restlessness' or 'increased psychomotor activity', dream type is 'absurd', source of the dream is 'internal organic pathology' or 'somatic stimuli' and dream mechanisms involved are 'displacement', 'representation', 'secondary revision', 'projection', 'inversion' and 'condensation'.

\section{'Parisamvatsaraad yasya -- yatha preta stathaiva sa' $(\text { Verse } 18)^{3,4}$}

The person who has been suffering with continuous or prolonged or persistent fever (jwara), which occurs both in hot and cold seasons (ushno va yadi va sheeto) and having more than a year duration (parisamvatsaraad) should be considered as already dead (yatha preta stathaiva sa). A number of bacterial, viral, parasitic and fungal infections can cause prolonged fever (parisamvatsaraad jwara). Many infectious agents cause a chronic and low grade fever (parisamvatsaraad jwara). Chronic infections can be categorised according to the type of organism such as bacterial causes (osteomyelitis, occult abscess, bacterial endocarditis, Rickettsia, Coxiella, Bartonella spp, enteric fever, tuberculosis, brucellosis and yersiniosis), parasitic causes (leishmaniasis and malaria), infectious mononucleosis (caused by EBV, CMV and Toxoplasma cause a fever lasting more than three weeks), endemic fungi (deep seated mycoses), and other opportunistic pathogens that can present with FUO in immunosuppressed individuals (yatha preta stathaiva sa), such as those with chronic renal impairment and HIV. ${ }^{65}$ Sepsis accounts for $74 \%$ of fever in hospitalised patients and, of the remainder, malignancy, tissue ischaemia, and drug reactions account for the majority. Patients exposed to higher temperatures and for longer periods of time (parisamvatsaraad jwara) are more at risk of complications such as multi organ failure and death in extreme cases (yatha preta stathaiva sa). ${ }^{66}$ Persistent fever (parisamvatsaraad jwara) suggests resistant bacteria, a viral cause, unsuitable antibiotic or a complication of OM. Unexplained persistent and recurrent fever (parisamvatsaraad jwara) for more than a month is considered as a moderate severe HIV (yatha preta stathaiva sa?). Persistent or prolonged fever (parisamvatsaraad jwara) can also be seen in aseptic or $\mathrm{TB}$ meningitis, pulmonary $\mathrm{TB}$, disseminated $\mathrm{TB}$, miliary $\mathrm{TB}$, and in EPTB. Children with combined intrapulmonary and EPTB have a higher peak and a longer duration of fever (parisamvatsaraad jwara). ${ }^{67}$ The present verse denotes prolonged fever caused by a wide variety of conditions associated with poor prognosis

\section{'Yasya jaata pramehasya -- yatha preta stathaiva sa' (Verse 19) ${ }^{3,4}$}

Manifestation of carbuncles (pitaka) or sinuses (shatapada) or multiple pus points (shatapada or pitaka paandura) other complications (upadrava) in congenital diabetes (jaata prameha) patients denotes an 
impending death (yatha preta stathaiva sa). Skin carbuncle (pitaka) is a necrotizing infection of the skin and subcutaneous tissues composed of a cluster of furuncles with multiple draining sinuses (shatapada). Carbuncles usually open and drain through multiple channels (shatapada). They are commonly associated with diabetic patients (jaata prameha). Skin and soft tissue infections are common in diabetics (especially when uncontrolled) (jaata prameha). The bacteria penetrate the skin and the subcutaneous tissues to form a series of communicating abscesses (pitaka paandura?), which discharge by separate opening on the surface (sieve like appearance) (shatapada). ${ }^{68}$

'Yasyordhwam kramate vaayu -- yatha preta stathaiva sa' (Verse 20) $)^{3,4}$

The person (yasya), in whom the aggravated vaayu traverses (kramate) upper parts of the body (urdhwam) up to the ears (shrotram) and all over the body (adha pravartate \& sarvaani cha) causing pain (rupturing type) (prabhidyate) should be considered as dead (yatha preta stathaiva sa). An increased risk of death (yatha preta stathaiva sa) in people (yasya) with chronic pain (vaataja), particularly from cancer has been established. Musculoskeletal pain (vaataja) may also be associated with increased mortality (yatha preta stathaiva sa). Chronic pain (which lasts for three months or longer) (kramate vaayu) is experienced by $30 \%$ (approximately) of adults (yasya) and commonly occurs in multiple body sites (urdhwam, adha, shrotram and sarvaani). Chronic widespread pain (urdhwam, adha, shrotram and sarvaani vaayu) is a phenotype that captures people (yasya) with more severe pain (vaataja) that has a greater impact on outcomes (yatha preta stathaiva sa). Few studies have established the positive association between chronic or widespread pain (urdhwam, adha, shrotram and sarvaani vaayu) and an increased rate of all-cause mortality (yatha preta stathaiva sa). Significant associations between chronic or widespread pain (urdhwam, adha, shrotram and sarvaani kramate vaayu) and increased risk of death (yatha preta stathaiva sa) from cancer, cardiovascular disease, cerebrovascular disease, liver cirrhosis, influenza, pneumonia and septicaemia were reported. ${ }^{69}$
The present verse denotes wide variety of conditions such as vascular (acute arterial occlusion, arterial embolus, aortic dissection, arterial thrombosis, TAO, PAD, haemorrhage, cardiovascular and cerebrovascular diseases etc.) or neurological (peripheral neuropathies, myelopathies, myelitis, neuroinflammatory, neurodegenerative, demyelinating conditions) or musculoskeletal (myopathies, infectious $\&$ non-infectious myositis, autoimmune inflammatory disease, connective tissue diseases, degenerative diseases etc.) or malignancy related or infectious etc. associated with poor prognosis.

\section{'Ityete lakshanai yuktam -- rakshaan aatma yasha sphutam' $\left(\right.$ Verse 21) ${ }^{3,4}$}

The brave (veero) and wise (dheero) physician (bhishak) should not attempt to treat (nopakrameta) the patient (evam maanavam), who displays the signs and symptoms mentioned in this chapter (ityete lakshanai yuktam). Physician can protect his fame or reputation (rakshaan aatma yasha) by avoiding such patients (who displays the signs and symptoms mentioned in this chapter). Treating incurable diseases leads to financial losses, defamation, loss of reputation, social harm, liability to legal punishments etc. to the concerned physician. Hence physician should avoid treating incurable diseases to protect his reputation and dignity. ${ }^{5}$ The conditions explained in the present chapter represent NBT especially at the EOL stages, which are futile and physician should avoid treating such patients. Attempt to treat conditions with high mortality rates or poor prognosis seen especially at EOL stages may generate false hope, inappropriate use of scarce healthcare resources or infrastructure and staff dissatisfaction with anticipated poor outcomes. Most of the ICU patients will die no matter how best the treatment is provided to them (just like the conditions explained in the current chapter). Medically inappropriate care aggravates pain, suffering, and discomfort to the patients. ${ }^{70}$ According to 'Maharshi Bhela', patients with EOL stages should not be treated (as they won't receive any benefit to the treatments no matter how good they are).

Table I Contents of 'Gomaya churneeyam' chapter

\begin{tabular}{|c|c|}
\hline Verse & Relevant condition \\
\hline ‘purnam shirasi yasyaiva -- maasaaddeham jahaati sa’(B. I. 9/I) & Seborrheic dermatitis in immunocompromised patient or AIDS patients; \\
\hline ‘krushasya kapha rogena -- dvau maasau naativartate’(B. I. 9/2) & $\begin{array}{l}\text { Tuberculosis or extra pulmonary tuberculosis or lung carcinoma with } \\
\text { metastasis to middle ear \& temporal bone; }\end{array}$ \\
\hline $\begin{array}{l}\text { 'yasya lohitakaabhaasa -- } \\
\text { sa maasam naativartate'(B. I. 9/3) }\end{array}$ & $\begin{array}{l}\text { Nasopalatine duct cyst;Aneurysmal bone cyst; radicular cysts, hemangiomas, } \\
\text { squamous cell carcinoma, non-Hodgkin's lymphoma, and metastasis in the } \\
\text { oral cavity and maxillofacial region; }\end{array}$ \\
\hline 'arundhati na pashyet -- kshipram praan aur vimuchyate’(B. I. 9/4) & $\begin{array}{l}\text { Visual impairment due to various ocular and systemic diseases associated } \\
\text { with mortality; Age related macular degeneration; Cataract; }\end{array}$ \\
\hline $\begin{array}{l}\text { 'anukaabhishcha -- } \\
\text { na sa jeevati taadrusha'(B. I. 9/5) }\end{array}$ & $\begin{array}{l}\text { Oral malignant melanoma; Laugier-Hunziker syndrome; Peutz-Jeghers } \\
\text { syndrome; }\end{array}$ \\
\hline ‘sheershaabhitaapino -- naayamasteeti nirdishet’(B. I. 9/6) & $\begin{array}{l}\text { Short-lasting unilateral neuralgiform headache attacks with conjunctival } \\
\text { injection and tearing; Trigeminal autonomic cephalgia; Neuromyelitis optica } \\
\text { spectrum disorder; }\end{array}$ \\
\hline ‘yasya lomaani keshaashcha -- na sa jeevati taadrusha’(B. I. 9/7) & $\begin{array}{l}\text { Systemic lupus erythematosus; Autonomic dysreflexia; Spinal cord injury; } \\
\text { Ictal piloerection; Temporal lobe epilepsy; Limbic encephalitis; }\end{array}$ \\
\hline $\begin{array}{l}\text { 'yasya kaalaantare dantaa -- } \\
\text { na sa jeevati taadrusha'(B. I. 9/8) }\end{array}$ & Periodontitis; White spot lesions; Congenital erythropoeitic porphyria; \\
\hline 'kshaarena vidhrutam gaatram -- na cha sa jeevati taadrusha'(B. I. 9/9) & Changes of skin colour and temperature at end stages of life; \\
\hline $\begin{array}{l}\text { 'gaatreshu swara varneshu -- } \\
\text { na cha sa jeevati taadrusha'(B. I. 9//0) }\end{array}$ & $\begin{array}{l}\text { Skin colour changes and diminished voice at end stages of life; } \\
\text { Hyperhidrosis and seborrhoea in Parkinson's disease; }\end{array}$ \\
\hline
\end{tabular}


Table Continued.

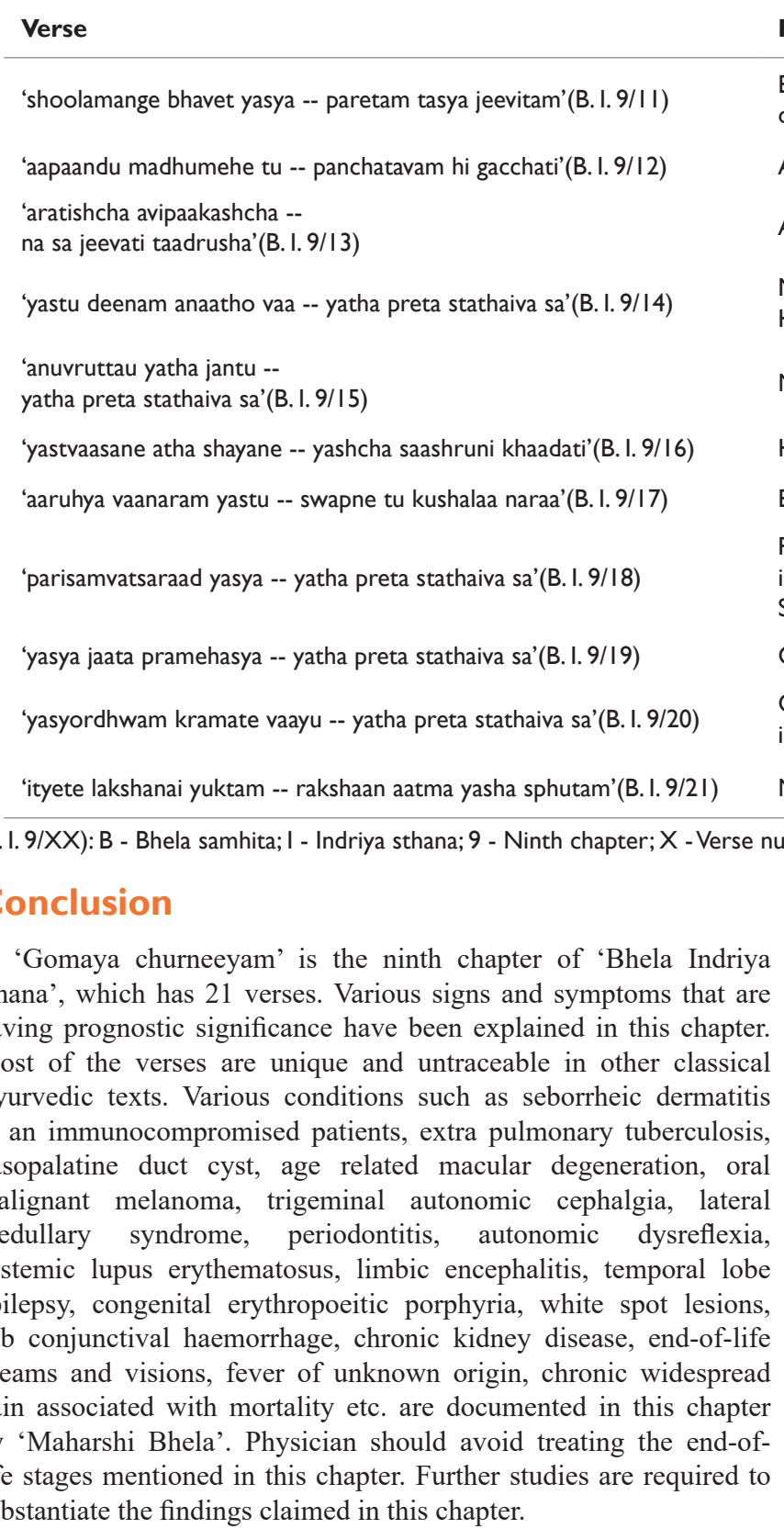

\section{Acknowledgments}

None.

\section{Conflicts of interest}

Author declares that there are no conflicts of interest.

\section{Funding}

None.

\section{References}

1. Maharshi Bhela. Bhela Samhita, commentary, translation and critical notes by Krishnamurthy KH. In: Sharma PV, 1st edn. Introduction. Varanasi: Chaukhamba visvabharati; 2008. p. 9-20.

2. Maharshi Bhela. Bhela Samhita. In: Abhay Katyayan, 1st edn. Introduction Varanasi: Chaukhamba Surbharati Prakashan; 2009. p. 5-14.

\section{Relevant condition}

Eye bleeding associated with systemic or rheumatological or autoimmune disorders; Sub conjunctival haemorrhage; Carotid cavernous fistula;

Anaemia associated with diabetes or chronic kidney disease or renal failure;

Anorexia-cachexia syndrome with delirium;

Major depressive disorder; Catatonia; Negative symptoms of Schizophrenia; Hypochondriasis;

Non-traumatic coma due to various causes;

Hyperactive or agitated delirium;

End-of-life dreams and visions; Delirium;

Persistent or prolonged fever due to infectious agents; Fever in immunocompromised patients; Tuberculosis; Extra pulmonary tuberculosis; Sepsis;

Carbuncles, sinuses and other complications associated with diabetes;

Chronic, widespread pain due to vascular, neurological, musculoskeletal, infectious, and carcinoma related conditions associated with mortality;

Non-beneficial treatments at end-of-life stages; by Krishnamurthy KH. In: Sharma PV, 1st edn. Gomaya churneeyam adhyaya. Verse 1-21. India, Varanasi: Chaukhamba Visvabharati; 2008. p. 269-273.

4. Maharshi Bhela. Bhela Samhita. In: Abhay Katyayan, 1st edn. Gomaya churneeyam adhyaya. Verse 1-21. India, Varanasi: Chaukhamba surbharati prakashan; 2009. p. 273-276.

5. Mamidi P, Gupta K. Varna swareeyam of Charaka Indriya sthana - An explorative study. Int J Ayu Alt Med. 2019;7(5):152-175.

6. Gupta K, Mamidi P. Pushpitakam of Charaka Indriya sthana - An explorative study. Int J Ayu Alt Med. 2019;7(5):176-182.

7. Mamidi P, Gupta K. Parimarshaneeyam of Charaka Indriya sthana - An explorative study. Int J Ayu Alt Med. 2019;7(5):183-191.

8. Gupta K, Mamidi P. Indriyaaneekam of Charaka Indriya sthana - An explorative study. Int J Ayu Alt Med. 2019;7(5):192-202.

9. Mamidi P, Gupta K. Purvarupeeyam of Charaka Indriya sthana - An explorative study. Int J Ayu Alt Med. 2019;7(5):203-212.

10. Gupta K, Mamidi P. Katamani shaririyam of Charaka Indriya sthana - An explorative study. Int J Ayu Alt Med. 2019;7(5):213-222.

11. Mamidi P, Gupta K. Panna rupeeyam of Charaka Indriya sthana - An explorative study. Int J Ayu Alt Med. 2019;7(6):223-235.

12. Gupta K, Mamidi P. Avaak shirasiyam of Charaka Indriya sthana - An explorative study. Int J Ayu Alt Med. 2019;7(6):236-251.

13. Mamidi P, Gupta K. Yasya shyaava nimitteeyam of Charaka Indriya sthana - An explorative study. Int J Ayu Alt Med. 2019;7(6):252-263.

14. Gupta K, Mamidi P. Sadyo maraneeyam of Charaka Indriya sthana - An explorative study. Int J Ayu Alt Med. 2019;7(6):264-273.

15. Mamidi P, Gupta K. Anu jyoteeyam of Charaka Indriya sthana - An explorative study. Int J Ayu Alt Med. 2019;7(6):274-287.

16. Gupta K, Mamidi P. Gomaya choorneeyam of Charaka Indriya sthana An explorative study. Int J Ayu Alt Med. 2019;7(6):288-306.

17. Mamidi P, Gupta K. Neurological conditions in Charaka Indriya sthana - An explorative study. Int J Complement Alt Med. 2020;13(3):107-119. 
18. Gupta K, Mamidi P. Dementia, delirium \& neuropsychiatric conditions in Charaka indriya sthana. Pharm Pharmacol Int J. 2020;8(5):297-310.

19. Gupta K, Mamidi P. Sadyo maraneeyam of Bhela indriya sthana - An explorative study. Int J Complement Alt Med. 2020;13(5):185-191.

20. Ording AG, Veres K, Farkas DK, et al. Risk of cancer in patients with epistaxis and haemoptysis. Br J Cancer. 2018;118(6):913-919.

21. Corey R. Hemoptysis. In: Walker HK, Hall WD, Hurst JW, editors. Clinical Methods:The History, Physical, and Laboratory Examinations. 3rd edn. Boston: Butterworths; 1990.

22. Sørensen H. Cancer of the middle ear and mastoid. Acta Radiologica 1960;54(6):460-468.

23. Singh S, Garg N, Gupta S, et al. Fine needle aspiration cytology in lesions of oral and maxillofacial region: Diagnostic pitfalls. J Cytol. 2011;28(3):93-97.

24. Shylaja S, Balaji K, Krishna A. Nasopalatine duct cyst: report of a case with review of literature. Indian J Otolaryngol Head Neck Surg. 2013;65(4):385-388.

25. Debnath SC, Adhyapok AK, Hazarika K, et al. Aneurysmal bone cyst of maxillary alveolus:A rare case report. Contemp Clin Dent. 2016;7(1):111113.

26. Diwan A, Bhagavaldas MC, Bagga V, et al. Multidisciplinary Approach in Management of a Large Cystic Lesion in Anterior Maxilla - A Case Report. J Clin Diagn Res. 2015;9(5):41-43.

27. Bharti V, Singh J. Capillary hemangioma of palatal mucosa. J Indian Soc Periodontol. 2012;16(3):475-478.

28. Clemons TE, Kurinij N, Sperduto RD, et al. Associations of mortality with ocular disorders and an intervention of high-dose antioxidants and zinc in the Age-Related Eye Disease Study: AREDS Report No. 13. Arch Ophthalmol. 2004;122(5):716-726.

29. McCarty CA, Nanjan MB, Taylor HR. Vision impairment predicts 5 year mortality. Br J Ophthalmol. 2001;85(3):322-326.

30. Zheng DD, Christ SL, Lam BL, et al. Increased mortality risk among the visually impaired:the roles of mental well-being and preventive care practices. Invest Ophthalmol Vis Sci. 2012;53(6):2685-2692.

31. Bradley G. Diseases of the oral mucosa. Can Fam Physician. 1988;34:1443-1451.

32. Duan N, Zhang YH, Wang WM, et al. Mystery behind labial and oral melanotic macules:Clinical, dermoscopic and pathological aspects of Laugier-Hunziker syndrome. World J Clin Cases. 2018;6(10):322-334.

33. Babburi S, Subramanyam RV, Aparna V, et al. Intraoral malignant melanoma. Niger Med J. 2013;54(4):278-281.

34. Uchino K, Lu M. Paroxysmal rhinorrhea after medullary infarct. Case Rep Neurol. 2012;4:28-30.

35. Park MH, Kim BJ, Koh SB, et al. Lesional location of lateral medullary infarction presenting hiccups(singultus). J Neurol Neurosurg Psychiatry. 2005;76(1):95-98.

36. Liu FC, Fuh JL, Wang SJ. Symptomatic trigeminal autonomic cephalalgia associated with allodynia in a patient with multiple sclerosis. J Chin Med Assoc. 2008;71(11):583-586.

37. Ho KW, Przkora R, Kumar S. Sphenopalatine ganglion:Block, radiofrequency ablation and neurostimulation - A systematic review. $J$ Headache Pain. 2017;18(1):118.

38. Mizuno Y, Shinoda K, Watanabe M, et al. Short-lasting unilateral neuralgiform headache attacks with cranial autonomic symptoms in NMOSD. Neurol Neuroimmunol Neuroinflamm. 2018;5(3):447.

39. Concha JSS, Werth VP. Alopecias in lupus erythematosus. Lupus Sci Med. 2018;5(1):e000291.
40. Allen KJ, Leslie SW. Autonomic Dysreflexia. In: StatPearls. Treasure Island(FL): StatPearls Publishing; 2020.

41. Milligan J, Lee J, McMillan C, et al. Autonomic dysreflexia: recognizing a common serious condition in patients with spinal cord injury. Can Fam Physician. 2012;58(8):831-835.

42. Kumar A, Maini K, Arya K, et al. Simple Partial Seizure. In: StatPearls. Treasure Island(FL): StatPearls Publishing; 2020.

43. Loddenkemper T, Kellinghaus C, Gandjour J, et al. Localising and lateralising value of ictal piloerection. J Neurol Neurosurg Psychiatry. 2004;75(6):879-883.

44. Yang J, Sun Q, Yang G. Pilomotor seizures in a patient with LGI1 encephalitis. Front Neurol. 2020;11:61.

45. Janse MJ. Electrophysiological changes in heart failure and their relationship to arrhythmogenesis. Cardiovasc Res. 2004;61(2):208-217.

46. Mortazavi H, Baharvand $\mathrm{M}$, Khodadoustan A. Colors in tooth discoloration: A new classification and literature review. Int J Clin Dent. 2014;7(1):17-28.

47. Singh SP, Fält P, Barman I, et al. Objective identification of dental abnormalities with multispectral fluorescence imaging. $J$ Biophotonics. 2017;10(10):1279-1286.

48. Tung MS, Eichmiller FC. Amorphous calcium phosphates for tooth mineralization. Compend Contin Educ Dent. 2004;25(9):9-13.

49. Meyers IA. Minimum intervention dentistry and the management of tooth wear in general practice. Aust Dent J. 2013;58:60-65.

50. Hirakawa Y, Uemura K. Signs and Symptoms of Impending Death in Endof-life Elderly Dementia Sufferers:Point of View of Formal Caregivers in Rural Areas: A Qualitative Study. J Rural Med. 2012;7(2):59-64.

51. Crow FM. Final days at home. Can Fam Physician. 2014;60(6):543-545.

52. Brackenrich J, Fagg C. Hyperhidrosis. In: Stat Pearls. Treasure Island(FL): StatPearls Publishing; 2020.

53. Skorvanek M, Bhatia KP. The Skin and Parkinson's Disease:Review of Clinical, Diagnostic, and Therapeutic Issues. Mov Disord Clin Pract. 2016;4(1):21-31.

54. Tarlan B, Kiratli H. Subconjunctival haemorrhage: Risk factors and potential indicators. Clin Ophthalmol. 2013;7:1163-1170.

55. Petris CK, Almony A. Ophthalmic manifestations of rheumatologic disease:diagnosis and management. Mo Med. 2012;109(1):53-58.

56. Antwi-Bafour S, Hammond S, Adjei JK, et al. A case-control study of prevalence of anaemia among patients with type 2 diabetes. $J$ Med Case Rep. 2016;10:110.

57. Kennedy SH. Core symptoms of major depressive disorder:relevance to diagnosis and treatment. Dialogues Clin Neurosci. 2008;10(3):271-277.

58. Rasmussen SA, Mazurek MF, Rosebush PI. Catatonia: Our current understanding of its diagnosis, treatment and pathophysiology. World $J$ Psychiatry. 2016;6(4):391-398.

59. Correll CU, Schooler NR. Negative Symptoms in Schizophrenia:A Review and Clinical Guide for Recognition, Assessment, and Treatment. Neuropsychiatr Dis Treat. 2020;16:519-534.

60. Pavithra N, Dahale AB, Desai G, et al. Hypochondriasis:Clinical Profile in a Tertiary Care Psychiatry and Neurosciences Hospital in Southern India - A Retrospective Chart Review. Indian J Psychol Med. 2019;41(2):178181.

61. Cooksley T, Rose S, Holland M. A systematic approach to the unconscious patient. Clin Med(Lond). 2018;18(1):88-92.

62. Harris D. Delirium in advanced disease. Postgrad Med J. 2007;83(982):525-528. 
63. Grant P, Wright S, Depner R, et al. The significance of end-of-life dreams and visions. NursTimes. 2014;110(28):22-24.

64. Roberts BL, Rickard CM, Rajbhandari D, et al. Patients' dreams in ICU recall at two years post discharge and comparison to delirium status during ICU admission. A multi centre cohort study. Intensive Crit Care Nurs. 2006;22(5):264-273.

65. McGregor AC, Moore DA. Infectious causes of fever of unknown origin Clin Med(Lond). 2015;15(3):285-287.

66. Walter EJ, Hanna-Jumma S, Carraretto M, Forni L. The pathophysiological basis and consequences of fever. Crit Care. 2016;20(1):200.
67. El-Radhi AS. Fever in Common Infectious Diseases. Clinical Manual of Fever in Children. 2019. p. 85-140.

68. Jain AKC, Nisha ST, Viswanath S. Carbuncle in diabetics - Our experience. Sch J App Med Sci. 2013;1(5):493-495.

69. Smith D, Wilkie R, Uthman O, et al. Chronic pain and mortality:a systematic review. PLoS One. 2014;9(6):e99048.

70. Cardona-Morrell M, Kim JC, Turner RM, et al. Non-beneficial treatments in hospital at the end of life:a systematic review on extent of the problem. Int J Oual Health C. 2016;28(4):456-469. 